Aleh Kabiak ${ }^{1}$

Iryna Andras ${ }^{2}$

Department of Sociology

Faculty of Philosophy and Social Sciences

Belarusian State University

Minsk (Republic of Belarus)
UDC 316.644-057.875:327(476)"2014"

Original scientific paper

Submitted 24/07/2019

Revised 03/09/2019

Accepted 08/09/2019

doi: 10.5937/socpreg53-22288

\title{
SOCIAL ATTITUDES OF BELARUSIANS TOWARDS INTEGRATION: BETWEEN THE EUROPEAN UNION AND THE EURASIAN ECONOMIC UNION ${ }^{3}$
}

Abstract: The location of Belarus between the Russian Federation and the European Union placed before the Republic a clear choice between the East and the West. Currently in the integration processes, there is also a heavy skew towards Russia due to historic and economic reasons. Public opinion is in favour of integration primarily with Russia (75.1\%), according to the republican opinion survey Belarus-2030 conducted by the Institute of Sociology of National Academy of Sciences of Belarus (Minsk) in 2014, and the majority of the Belarusian population does not seek to join Europe. Therefore, the present-day formula of governmental (foreign policy) and people's (social attitudes of the population) geopolitics of Belarus would be independence but with brotherly Russia.

Keywords: social attitudes, integration, Belarus, Russia.

\section{Introduction}

After the fall of the Berlin wall in November 1989 and- the disintegration of the Soviet Union and Yugoslavia which followed, former Soviet countries started to move actively towards European reintegration. Thus, the assumptions of some representatives of the European Economic Community (the basis of the European Union), made as early as in the 1970s, started to come true. Such assumptions stated that "certain communist states will knock at the doors of the European economic community... - this is just a question of time". At that time, the leaders of socialist countries considered such point of view a pure fantasy (Alekseev, Vikentyev, Miroshnichenko, 1975, p. 45). However, when the Council for Mutual Economic Assistance (COMECON) ceased to exist in 1991, the story of socialist economic integration ended. Former communist countries, which joined the European Union, gradually began to acquire the characteristics of "typical" international

1 aleh.kabiak@yahoo.com;

2 iryna.andras@gmail.com;

3 The report on this topic was presented at the 13th ESA Conference (Un)Making Europe: Capitalism, Solidarities, Subjectivities, Athens (Greece), 29.08.- 01.09.2017. 
trade areas, including their political activities. As for Belarus, it became one of the few countries in Europe which did not ask for membership in the European Union. Neither did the European Union offer friendship to Minsk (Korosteleva, 2009). In terms of political integration, the location of Belarus between the Russian Federation and the European Union placed before the Republic a clear choice between the East and the West. Due to pragmatic, economic and politically calibrated reasons, Belarus started to actively revive broken ranks with the former soviet states. The socio-cultural reason also played an important role: during the Soviet Union Referendum of March 17, 1991, held after the adoption of the Declaration on the State Sovereignty of the Republic of Belarus (27 July 1990), $82.7 \%$ of the population of the Republic voted for the preservation of the USSR. Thus, the eastern direction in the foreign policy of Belarus was chosen out of necessity. Since then, 27 years have passed. It would appear that Belarus, as an independent state, has the right of free choice regarding international integration. At present, commonly asked questions are: "What choice does Belarus make today: the West or the East?" "The European Union or the Eurasian Economic Union?" However, in our sociological study dedicated to the involvement of Belarus in the integration processes, we raise a different question: "Does Belarus have any choice at all?"

\section{Research approach}

The geopolitical location of Belarus provides the country with certain advantages in terms of manipulative influence. This being said, after the disintegration of the Soviet Union, Belarus defined itself as a strategically significant junction between the East and the West, in geopolitical terms. In this context, the Belarusian government aims at a wellbalanced multi-faceted foreign policy. This is primarily due to the fact that Belarus is geopolitically located at the junction of the routes North-South-West-East. To the West, there are countries of Central and Eastern Europe (Poland, Czech Republic, Slovakia, Hungary), which are part of one of the biggest geopolitical centres - the European Union. To the North-West, there are Baltic countries, which are also actively integrating in the European Union. To the South, there are countries of the Black Sea region (Ukraine, Moldova and the countries of South-West Asia). To the East, there is the Russian Federation. In the North-South direction, Belarus is a connecting bridge between the Black Sea region and the Baltic region. In the East-West direction, Belarus is the main corridor for Russia and the countries of Central Asia developing economic relations with the European Union. Thus, transit is one of the key factors of lobbying the interests of Belarus in the international arena. Along with that, Belarus is not the only transit corridor between Russia and Europe. That is why any attempt to make additional profit by increasing transit charges may cause the shifting of the main traffic flows to the territories of the Baltic countries and Ukraine. This also concerns Russian energy products- the slightest increase of the cost in the Belarusian territory entails tension in the relations not only with Russia, but also with the consumers of Russian energy products in the Baltic countries and in Europe (in particular, the relations with Poland, Germany).

That is why, despite its pursuance of neutrality, Belarus constantly shows high geopolitical valence. The Republic is a member of three most important unions of post-Soviet countries: the Commonwealth of Independent States (CIS), the Union State of Russia 
and Belarus (US), the Eurasian Economic Union (EAEU). The centre of gravity in these unions is Russia. So far, the most heated debates concern the Eurasian Economic Union (EAEU). However, today European integration within the European Union is as close to the Belarusian boarders as it could ever be. This constantly makes the authorities and the citizens of the Republic consider close integration with Europe. Even though the future of Belarus within the European Union has never been mentioned, the state media constantly addresses the advantages and disadvantages of the Eurasian and the European integration for Belarus. The success of integration processes also depends on the expectations and the social attitudes which determine and motivate people's behavior.

In the theoretical part, the authors adhere to the world-systems theory, proposed by sociologist I. Wallerstein (Wallerstein, 2004). We consider society as an institutionally integrated territorial community with a single identity. The processes that take place in post-Soviet societies are largely formatted by broad global associations such as the European Union, the Eurasian Economic Union, the "community of common destiny" formed by China around the Silk Road Economic Belt (SREB), etc.. These associations are integral spaces of socio-historical development - cultural-historical worlds (Russian world, Chinese world). Societies also develop, but only as part of the cultural and historical worlds that embrace them. Therefore, the integration and internal dynamics of a certain world should be considered not only as a discussion topic of external political, cultural and informational influence, but first of all as the question of development - the problem of socio-historical perspective and effective modernization. For example, after the collapse of the USSR, the question of political and socio-economic relations between the former republics in the format of relations between sovereign states became very relevant. In 1993-1997, the idea of integration of the post-Soviet space within the so-called "Russian world" (or "Russkiy Mir" in Russian) grew. In the 19th century, the famous Russian dramatist A.N. Ostrovsky used the "Russian World" as a literary metaphor. At the end of the 20th century, the historian and social anthropologist V.A. Tishkov (Tishkov, 1993a; Tishkov, 1993b) introduced this term into scientific discourse considering it as a globalscale phenomenon. We set ourselves with the task of studying the social expectations of Belarusians towards integration with both Russia (the core of the Russian world) and the European Union.

The results of the republican opinion survey Belarus-2030 conducted by the Sociology Institute of Belarus in 2014 became the main empirical base. It included random sampling with a controlled share of population aged 16 and older according to the area of residence, gender, age and education. The representativeness of sampling is provided by the observance of the following terms: the sample proportionally includes the population of Minsk (distinguishing the city of Minsk), Mogilev, Vitebsk, Grodno, Gomel and Brest Regions; the urban and rural population; within the regions, the population of six "areas" is proportionally represented ( $1-$ the city of Minsk and administrative centres; 2 - cities with the population from 100 up to 250 thousand people; 3 - cities with the population from 50 up to 100 thousand people; 4 - cities with the population from 10 up to 50 thousand people; 5 - urban-type settlements with the population fewer than 10 thousand people; 6 - rural population). In each "area", the population according to gender, age, education is proportionally represented. The sample volume was 1495 respondents. 
The margin of sampling error is five percentage points. Monitoring data for different years were also used.

\section{Results: choosing the Eastern direction, the Western direction - still through Russia}

Belarusian foreign policy is traditionally seen from the point of view of a choice between the European Union and Russia (Allison, White, Light, 2005; Rotman \& Veremeeva, 2011; Marples, 2013). As we found, Belarus being part of the USSR for more than 70 years has linked the Republic to the Russian Federation both politically and economically. What can one say about socio-cultural interests of Belarus and Russia? How strong is the sense of community between Belarusians and Russians and what is it based on? How does this unity apply in interstate relations?

We would like to start the study of social attitudes of Belarusians towards integration by answering the following question: Do Belarusian people see their country as an independent and a self-sustained state? In 2014, 36.3\% of the respondents answered "yes" to this question, 38.6\% - "mostly yes", 8.1\% - "mostly no", 3.5\% - "no", 13.3\% - were undecided, $0.2 \%$ - did not answer. Thus, $74.9 \%$ of Belarusians (the total of the shares of "yes" and "mostly yes" answers) see their country as an independent and a self-sustained state. However, when answering the question What would you wish Belarus to be like in the international arena in 10-15 years? $22.3 \%$ only chose the option of the state preserving neutrality and not being in any unions and blocks. The majority of the population of Belarus (53.6 $\%$ ) were in favour of different forms and directions of integration: $30.5 \%$ would like to see Belarus as a member of the Eurasian Economic Union (Russia, Belarus, Kazakhstan, etc.), $12.2 \%$ - as a member of the European Union, $10.9 \%$ - as a republic which is part of the Russian Federation.

The remaining $24.1 \%$ were either undecided $(21.8 \%)$ or gave alternative replies (2.3\%). When answering the question Are you in favour of tight [highlighted by the authors] integration of Belarus and Russia? 3/4 of the respondents generally answered affirmatively: 42.6\% - "yes", 32.5\% - "mostly yes"; 6.8\% - "mostly no", 2.9\% - "no", 14.9\% - were undecided, $0.3 \%$ - did not answer. This is the assessment of social attitudes of Belarusians towards integration provided by a state establishment - the Institute of Sociology. At the same time, non-state sociology research institutions confirm the geopolitical choice of Belarusians in favour of the union with the eastern partner. In 2016, a nationwide representative case study on the issue of What would Belarusians rather choose: an alliance with Russia or the European Union? was conducted. The main question was formulated as follows: In which union of states, in your opinion, the people of Belarus would be better off: in alliance with the Russian Federation or the European Union? The distribution of responses was as follows: the pro-Russian position was expressed by about $65 \%$ of respondents, the pro-European position - by $20 \%$ of respondents (Pieliasa, 2017).

Therefore, the social awareness of Belarusians is dominated by attitudes in favour of integration while preserving the independence. The "integrators" are clearly more likely to choose the eastern direction of partner relations. The integration mainstream in the eastern direction of social conscience would be Russia. How strong is the eastern direction of integration today? 
In order to assess the possible dynamics of social attitudes on integration, first we compared the distribution of answers of the respondents of different age groups. Within the groups of people younger than 40 , those who are distinctly in favour of the integration of Belarus with Russia make $32.8 \%$ to $34.3 \%$, whereas within the age groups of 40 and older - the share ranges from $44.8 \%$ to $53.2 \%$. That means Belarusians aged 40 and older, whose childhood and youth (at least) fell into the Soviet period, are more likely to reproduce social stereotypes of Russia being an elder brother in their minds. "We, Belarusians, together with brotherly Russia, looked for the road to happiness" - these are the first lines of the Belarusian state anthem in the Russian language when it was part of the Soviet Union as the Byelorussian Soviet Socialist Republic. As can be seen from the above, the elder generation tends to support the integration with Russia more than the younger one. Second, among Belarusians with higher education, the share of those distinctly in favour of tight integration (the answer "yes") is $39.8 \%$, and of those who are distinctly against it (the answer "no") $-4.9 \%$. The corresponding shares within lower education groups are between 42.0 to $44.0 \%$ and 1.7 to $2.7 \%$, respectively. As one can see, the education level does not have an impact on social attitudes of Belarus's population towards integration with Russia. Third, among the urban population, the share of people who generally support tight integration with Russia (the sum of shares of "yes" and "mostly yeas" answers) amounts to $73.5 \%(43.2+30.3 \%)$, and among the rural population it reached $79.7 \%(40.8$ $+38.9 \%$ ). The shares of those who are against integration (the total of shares of "no" and "mostly no" answers) are similar - 11.1\% (3.4 + 7.7\%) and 5.7\% (1.3+4.4\%), respectively. The place of residence also does not have a strong impact on the formation of social attitudes towards integration. As a result, representatives of older age groups to a greater extent support tight integration with Russia; citizens with higher education to a lesser extent favour tight integration with Russia; the urban population advocates tight integration with Russia less than the rural population does.

In theory, the support base of those in favour of tight integration with Russia could decrease due to urbanization, increase of the population having higher education and natural population decline, primarily, of older age groups. In such case, the integration of Belarus with Russia as a social project could be compared with the melting of Arctic ice. Seemingly still monumental, every year it becomes more fragile and vulnerable. However, after the crisis year of 2009, economic interaction between Belarus and Russia intensified: the customs union was established, the Eurasian Economic Community Anti-Crisis Fund (the EAEU's predecessor) supported Belarus in crisis, Russia again provided Belarus with preferential prices for oil and gas. As a result, in Belarus, after the crisis years of 2009-2011, the group of respondents with a negative attitude towards developing tighter relations between Belarus and Russia became almost twice smaller (Table 1.

However, speaking of the Eurasian Economic Union, one should not forget about the Union State of Russia and Belarus (or the Union State). Forming this Union triggered the establishemnt of other structures in the former Soviet territory including the Eurasian Economic Union. And the fact that the Union State has not ceased to exist proves that, despite new integration entities, Belarus and Russia stay the closest political, economic and military allies. This is supported by the results of social research into the BelarusianRussian integration in 2014 (Shavel, 2015). Thus, when defining the major goals of further development of the Union State of Russia and Belarus, the population thinks that 
the pooling of the resources of the two countries is the most important factor: Belarus - 45.2\%, Russia - 46.2\%. $34.5 \%$ of Belarusians (3rd place) and 35.6\% of Russians (2nd place) aim at a strong and powerful state, which one can be proud of. $26.7 \%$ of Belarusians and $31.7 \%$ of Russians (4th place each) see value in further alliance of the two Slavic republics in countering external threats. However, neither Russians (19.9\%) nor Belarusians (15.0\%) see the Union State as a state, which will bring the USSR back. Still, there are two times more Russians than Belarusians who think that the Union State should have a common political system ( $43.8 \%$ vs. $21.8 \%)$, economic system ( $49.5 \%$ vs. $24.7 \%)$ and ideology (57.6\% vs 24.2\%) (Shavel, 2015, p. 46). As Belarus has less experience, the exchange of experience in order to solve the problems of corruption, migration, the rise of living standards is more important for Belarusians than for Russians. (Belarus - 38.7\%, 2nd place; Russia $-31.6 \%$, 5 th place).

The integration of Belarus and Russia into one state has repeatedly become a hot topic. As early as the end of 1998, the Presidents A. Lukashenko and B. Yeltsyn signed the Declaration on further integration of the people of Belarus and Russia. This Declaration proclaimed the intention to create a common union state (which was eventually created - the Union State of Russia and Belarus) and it left the possibility of referendum concerning this issue open. The results of the survey of the population of Belarus and Russia showed that Belarusians had a more reserved attitude towards the idea of unification ("for" - 54.9\%), than the Russians did ("for"- 72.0\%) (Drakohurst, 1999, p. 79). In this context, there is a unique fact that, in 1999, during the survey, Belarusian respondents were asked "If the office of the President of Belarus and Russia was established, who would you vote for at the elections?" where only one politician could be named (Drakohurst, 1999, p. 80). The question itself did not trigger any concerns or irritation of the respondents. It seemed natural and the establishment of such an office - pretty possible. As a result, A. Lukashenko would be chosen as the President of Belarus and Russia by $38.4 \%$ of the respondents, including younger population $-25.7 \%$. The closest rival would be the Russian politician G. Yavlinsky - 5.2\% (including younger population - 4.5\%), who was ranked second. The sitting President B. Yeltsin won less than $1 \%$ of votes due to the lack of prior positive image and health problems. What was the reason behind the high rating of the Belarusian compared to the Russian leader? At the end of the 1990s, Russia lost the Chechen War, it lay in ruins after the default of 1998, hunger began in many regions. That is why, at the end of the 1990s, Belarus led by A. Lukashenko seemed very appealing for many Russians. It seemed that a growing crisis in Russia can be overcome by following Belarus's path. As early as in the 1990s, Belarus was consolidated under the reign of one person and was an administered state. Before Vladimir Putin took over the presidency, Russia was weaker in this respect. At present, Moscow has its own strong leader. As currently both states are strong and well administered, it is very difficult to raise the question of unification.

As one can see from the results of the surveys, the major problem of further development of the Union State is its institutional building, i.e. the creation of structures which would take up integration functions and successfully implement them. At present, Belarusians, as opposed to Russians, are satisfied with the existing differences between the institution structures of the Union State. The existence of two strong leaders in Belarus and in Russia makes the issue of unification of the two countries less relevant. 
In the circumstances, we direct your attention to the following interesting fact. When speaking of strengthening the integration with Russia, Belarusians are not ready to project the "Crimean crises" onto their own country (Tut.by, 2017). 68.3\% find the incorporation of Belarus into Russia, as was the case with the Crimea, improbable. Only $14.1 \%$ think similar actions of Russia towards Belarus possible. The majority of Belarusians (65.7\%) supported the decision on the annexation of the Crimea by Russia in 2014. Only 13.5\% called it illegal. Although the official Minsk took a neutral position in the Russian-Ukrainian conflict, the social attitude stating that the Russian Crimea was once given to Ukraine as a present remains strong. Russian mass media actively supports this attitude (for example, popular newspaper Komsomolskaya pravda) (Kp.by, 2004). At the same time, Kremlin has never raised the topic of annexation of Belarus by Russia (Belsat.eu, 2015). In Belarus, the share of population thinking that the Republic needs to be integrated into the Russian Federation as a subordinate entity is approximately 5-6\% (Table 2.

When difficulties arise with the functioning of different intra-state entities in the post-soviet territory, the union of Russia and Belarus becomes the starting point in the development of integration of the former Soviet republics. In our opinion, at present, the Union State is more than a political and economic project. The Union of Belarus and Russia has a powerful socio-cultural foundation. In our study, socio-cultural factors are ranked as top four factors that unite of Belarusian and Russian people, while economic, political and other common interests being hold the fifth place Table 3 .

Public mood of Belarusian citizens is a strong factor of successful implementation of social attitudes of Belarusians towards integration. When answering the question "How do you feel about the future of Belarus?", $25.1 \%$ of respondents chose the option "confident of a better life"; $45.0 \%$ - "hopeful of life improvement"; $4.9 \%$ - "apathetic and indifferent"; $9.6 \%$ - "concerned due to a possible life deterioration"; $6.5 \%$ - "worried due to the actual life deterioration"; $8.6 \%$ - were undecided; $0.3 \%$ - did not answer. If we rank informative answers from 1 (minimum) to 5 (maximum), the indicator of social optimism on a fivepoint scale will equal 3.8. In view of the above, the answers to the question: "Which of the following threats, in your opinion, endanger Belarus in the nearest 10-15 years?", are quite interesting. In order to assess the importance of a certain risk in the public consciousness of Belarusian citizens, we took the share of the respondents, who chose the option "This is rather possible" into consideration. The rating included the risks which can result from or relate to integration processes. As we can see, the share of those who have fears about the influx of migrants as an external factor of insecurity is high (30.5\%). Approximately three times fewer respondents mentioned a real risk of different kinds of intra-state ethnic or religious conflicts (11.4\%) Table 4.

As can be seen, Belarusians do not see real danger in the loss of sovereignty (7.9\%). The citizens of the Republic continue to actively support the accession into various economic unions Table 5.

Upon signing contracts within the framework of these Unions, the prospects of further integration of the countries immediately became visible. As forming of the Eurasian Customs Union, Common Economic Space, the Eurasian Economic Community, the Eurasian Economic Union received wide coverage in the national media, the data of a sociological survey detected a high level of public support of the accession of Belarus into these unions. 
The most likely benefits and advantages of the accession of Belarus into the Eurasian Economic Union, in the opinion of the respondents (2014), are: 1) the development of the market for the sale of Belarusian goods and services, the creation of more favourable conditions (duty-free trade, etc.) $(49.8 \%) ; 2$ ) the possibility to receive financial and other types of support in the conditions of crisis and global financial instability (44.6\%); 3) receiving energy products at preferential prices (37.4\%). The share of those who would like to receive energy products at preferential prices is likely to gradually decrease, as it made $40.6 \%$ in the age group of 40 and older and $33.7 \%$ in the age group of under 40 . This means that the younger generation, as compared to the older generation, to a lesser extent relies on benefits from Russia. Russians seem to have similar attitudes. According to the data of the All-Russian Public Opinion Research Center, Russians aged between 45 and 59 tend to favour equal prices for energy products in the union states (64.0\%), whereas with young people aged between 18 and 24 this share equals 44.0\% (VTSIOM, 2017).

Possible negative consequences of the accession of Belarus into the Eurasian Economic Union are the following: the migration of the most highly qualified specialists to the countries of the Eurasian Economic Union (41.8\%); the increase in customs duties and prices of a range of goods, as well as the loss of competitiveness of Belarusian goods and services in the domestic market as compared to the goods and services from other countries of the Eurasian Economic Union (31.9\% each); the destabilization of Belarusian economy upon the accession of the Republic into the Common Economic Union. (21.7\%); the transfer of powers in dealing with the key issues of economic development to the national level, as well as a loss or "blurring" of national culture and traditions (18.1\% each). The data of 2016 shows that Belarusians choose economic and political-military objectives as priority goals of the functioning of the Eurasian Economic Union (Table 6.

Regarding the discussion on the future of Belarus in integration with other countries, we rely on the results of the study "Young people in the post-Soviet space: pictures of the world, values, strategies of self-realization", conducted in October 2017 - February 2018 among the students from leading universities in Belarus and Russia (Andreev, Lashuk, 2019a; Andreev, Lashuk, 2019b). According to the secondary analysis of the findings of this study, Belarusian students have more positive than negative views about the Western world. For example, in the Belarusian sample, $28 \%$ of positive and $5 \%$ of negative reactions were recorded on the word "European Union", and in the Russian sample - $14 \%$ and $10 \%$; also, in Belarus the word "West" produced 34.5\% positive and 7\% negative reactions, in Russia - 27\% and 7\%. Belarusian students highly appreciate the Russian Federation as an important partner in the Union State of Russia and Belarus, associating Russia primarily with the words "strength" (64\%) and "tradition" (25\%). Students also evaluated the historical path that their countries have chosen: in Russia the ratio between optimists and pessimists in the student society is approximately 1:1.5 (24\%) while in Belarus it almost reaches $1: 4(42 \%)$. With that, Russian youth turns to the experience of modern China in the realm of search for new models of social development (such behavior is not typical of young Belarusians). The above is also true of integration. Young Russians support various integration initiatives and Belarus is one of the leading partners - more than $88 \%$ of Russian students expressed support. But in the priority list, Belarus ranked second to China. As a comparison, $82 \%$ of Russian students would like to develop integration with Kazakhstan, 75\% with the European Union, 52\% with the North Atlantic Treaty Organiza- 
tion (NATO), 42\% with Ukraine. Thus, Belarus will remain the leader in integration with Russia when it comes to gathering the Russian world and first of all this is the case with the Commonwealth of Independent States, the Union State of Russia and Belarus and the Eurasian Economic Union.

So, the respondents felt that the accession of Belarus into the Eurasian Economic Union has indisputable advantages (free movement of goods, services and finances, discounts on Russian energy products) and certain disadvantages (for example, labour migration, increased duties for oil export and decreased level of country's economy reform). Socio-economic and military-political goals are ranked the highest among the integration goals in the Eurasian Economic Union. Both Belarusian and Russian young people tend to favour the commercialization of the relations between the union states.

\section{Conclusion}

To sum up, the present-day foreign policy of the Republic of Belarus contains two basic postulates - the independence of the state and a multi-vector integration. Nevertheless, a well-balanced multi-faceted foreign policy officially proclaimed by the Belarusian President is obviously East-oriented. In the integration processes, there is also a heavy skew towards Russia due to historic and economic reasons. Although the majority of the Belarusian population supports different forms and vectors of integration, Belarusians do not seek to join Europe. The integration mainstream of Belarusian public consciousness is primarily directed towards Russia. Social attitudes of the Belarusian population regarding the integration relations with Russia are anchored on the social stereotype of the attitude to Russia as "the elder brother". Still, the level of partnership, which does not endanger the existence of Belarus as an independent state and would not prevent Belarus from returning to the family of the European nations, would meet national interests of Belarusians. That is, Belarusians aim at preserving independence and being with Russia.

As for a common policy with Russia, the failures of the eastern neighbor in the international arena have a rebound effect on Belarus as the eastern partner. At present, the imbalance of the eastern and the western vectors of Belarusian foreign policy substantially influences Belarusian national identity and its international positions. The deterioration of the relations with the West generates a negative impact on the socio-economic situation of Belarus and its international status. The normalization of relations with leading countries of the West and such influential international organizations as the European Union, the Council of Europe, NATO and the International Monetary Fund is a priority direction in the foreign policy of the Republic of Belarus. In order to reduce certain negative consequences of the Kremlin policy for Belarus from the point of the international community, the Republic is officially neutral. This position is especially strong with respect to military and political conflicts. Positive aspects of Russia's foreign policy are also projected onto Belarus, and Belarusians take it for granted.

The integration of Belarus with Russia is based on a powerful sociocultural foundation - common historic past, similar culture, shared language, family ties, inter-ethnic marriages. The integration attitudes of Belarusians towards Russia are dominated by cultural-historic factors, whereas the attitude towards being a member of the Eurasian Economic Union is clearly shaped by economic hopes and expectations: market development, 
additional investment opportunities and preferential prices for imported energy products. There is also an emerging trend towards being comfortable with the commercialization of the relations between Belarus and Russia, especially, among younger people. In the future, the main problem with the development of integration of the post-Soviet countries (also, within the framework of the Eurasian Economic Union) will be the creation of institutions and other structures which would assume and successfully implement integration functions. At present, the union of Belarus and Russia, which is based on common historic, socio-cultural, economic and political past, is the strongest in the territory of the former Soviet Union.

Therefore, the present-day formula of governmental (foreign policy) and people's (social attitudes of the population) geopolitics of Belarus would be the independence with Russia as strategic military partner. 
Олег Кобјак ${ }^{1}$

Ирина Андрас ${ }^{2}$

Департман за социологију

Факултет за филозофију и друштвене науке

Белоруски државни универзитет

Минск (Република Белорусија)

\title{
СТАВОВИ БЕЛОРУСА О ИНТЕГРАЦИЈИ: ИЗМЕЪУ ЕВРОПСКЕ УНИЈЕ И ЕВРОАЗИЈСКЕ ЕКОНОМСКЕ УНИЈЕ
}

\author{
(Превоg In Extenso)
}

Сажетак: Положај Белорусије између Руске Федерације и Европске уније ставио је пред Републику јасан избор између Истока и Запада. У процесима интеграције, тренутно постоји снажан наклон према Русији из историјских и економских разлога. Јавно мњење фаворизује интеграцију с Русијом (75,1\%), како је показало републичко истраживање јавног мњења Белорусија-2030 које је 2014. године спровео Институт за социологију Белоруске академије наука (Минск). Белоруско становништво не тежи придруживању Европи. Стога би данашња формула државне (спољне политике) и народне (ставови становништва) геополитике Белорусије била независност, али уз братску Русију.

Кључне речи: друштвени ставови, интеграција, Белорусија, Русија.

\section{Увод}

После пада Берлинског зида у новембру 1989. године, а затим и распада Совјетског Савеза и Југославије, бивше совјетске земље почеле су активно да се крећу ка европској реинтеграцији. Тако су претпоставке неких представника Европске економске заједнице (основа Европске уније), изречене још седамдесетих година прошлог века, почеле да се остварују. Такве претпоставке су говориле да ће „одређене комунистичке државе покуцати на врата Европске економске заједнице... - то је само питање времена“. У то време, лидери социјалистичких земаља сматрали су такво гледиште чистом фантазијом (Alekseev, Vikentyev, Miroshnichenko, 1975, стр. 45). Међутим, када је Савет за узајамну економску помоћ (СЕВ) престао да постоји 1991. године, прича социјалистичке економске интеграције се завршила.

\footnotetext{
1 aleh.kabiak@yahoo.com

2 iryna.andras@gmail.com

3 Извештај о овој теми представљен је на 13. конференцији Европске социолошке асоцијације под називом (Un)Making Europe: Capitalism, Solidarities, Subjectivities, Атина (Грчка), 29.08. 01.09.2017.
} 
Бивше комунистичке земље које су се придружиле Европској унији постепено су почеле да добијају карактеристике „типичних“ међународних трговинских подручја, такође по питању својих политичких активности. Белорусија је постала једна од ретких земаља у Европи која није тражила чланство у Европској унији. Ни Европска унија није понудила пријатељство Минску (Korosteleva, 2009). У погледу политичке интеграције, локација Белорусије између Руске Федерације и Европске уније ставила је пред Републику јасан избор између Истока и Запада. Из прагматичних, економских и политички калибрираних разлога, Белорусија је почела активно да оживљава разбијене редове с бившим совјетским државама. Социо-културни разлози су такође имали важну улогу: током Референдума о опстанку Совјетског Савеза 17. марта 1991. године, одржаног после усвајања Декларације о државном суверенитету Републике Белорусије (27. јула 1990.), 82,7\% становништва Републике је гласало за очување СССР-а. Дакле, источни правац у спољној политици Белорусије изабран је из нужде. Од тада је прошло 27 година. Чини се да Белорусија као независна држава има право слободног избора у погледу међународне интеграције. Тренутно су најчешћа питања следећа: „Какав избор прави Белорусија данас: Запад или Исток?“ „Европска унија или Евроазијска економска унија?“"Међутим, у нашој социолошкој студији посвећеној укључености Белорусије у процесе интеграције постављамо другачије питање: „Да ли Белорусија уопште има избора?“

\section{Приступ истраживању}

Геополитички положај Белорусије пружа земљи одређене предности у погледу манипулативног утицаја. После распада Совјетског Савеза, Белорусија се у геополитичком смислу дефинисала као стратешки значајан спој Истока и Запада. У том контексту, циљ белоруске владе јесте вођење уравнотежене вишестране спољне политике. Ово је превасходно резултат чињенице да се Белорусија геополитички на-

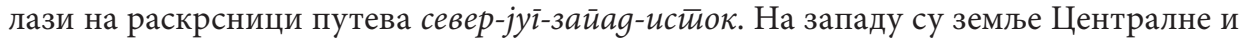
Источне Европе (Пољска, Чешка, Словачка, Мађарска), које су део једног од највећих геополитичких центара - Европске уније. На северозападу су балтичке земље, које се такође активно интегришу у Европску унију. На југу су земље црноморске регије (Украјина, Молдавија и земље југозападне Азије). На истоку је и Руска Федерација. У правцу север-југ, Белорусија је спојни мост између црноморског и балтичког региона. У правцу исток-запад, Белорусија је главни коридор Русије и земаља централне Азије које развијају економске односе са Европском унијом. Дакле, транзит је један од кључних фактора лобирања интереса Белорусије на међународној сцени. Уз то, Белорусија није једини транзитни коридор између Русије и Европе. Зато сваки покушај да се повећа приход повећањем транзитних накнада може да изазове преусмеравање главних саобраћајних токова на територије балтичких земаља и Украјине. Ово се такође тиче руских енергената, и најмањи пораст трошкова на белоруској територији повлачи за собом напетост у односима не само с Русијом, већ и са потрошачима руских енергената у балтичким земљама и Европи (посебно у односима са Пољском, Немачком).

Због тога, упркос тежњи ка неутралности, Белорусија стално показује високу геополитичку валенцију. Република је чланица три најважнија савеза постсовјетских 
држава: Заједнице независних држава (ЗНД), Савезне Државе Русије и Белорусије (СДРБ), Евроазијске економске уније (ЕАЕУ). Тежиште ових савеза је Русија. До сада су се најжешће расправе односиле на Евроазијску економску унију (ЕАЕУ). Међутим, данас је европска интеграција унутар Европске уније онолико близу белоруским границама колико је то уопште могуће. То је довело до ситуације да власти и грађани Републике учестало размишљају о блиској интеграцији са Европом. Иако се будућност Белорусије у оквиру Европске уније никада није спомињала, државни медији се непрестано баве предностима и недостацима евроазијске и европске интеграције Белорусије. Успех процеса интеграције такође зависи и од очекивања и друштвених ставова који одређују и мотивишу понашање људи.

У теоријском делу, аутори се придржавају теорије светских система коју је предложио социолог И. Валерштајн (Wallerstein, 2004). Друштво сматрамо институционално интегрисаном територијалном заједницом с јединственим идентитетом. Процесима који се одвијају у постсовјетским друштвима углавном обилују широке глобалне асоцијације као што су Европска унија, Евроазијска економска унија, „заједница заједничке судбине“ коју је Кина формирала око Економског појаса Пута свиле итд. Ове асоцијације су интегрални простори друштвено-историјског развоја - културно-историјски светови (руски свет, кинески свет). Друштва се такође развијају, али само као део културног и историјског света који их прихвата. Стога интеграцију и унутрашњу динамику одређеног света не треба посматрати само као тему за дискусију спољнополитичког, културног и информационог утицаја, већ пре свега као питање развоја - проблем друштвено-историјске перспективе и ефикасне модернизације. На пример, након распада СССР-а, питање политичких и друштвено-економских односа између бивших република као суверених држава постало је врло релевантно. У периоду 1993-1997 расла је идеја о интеграцији постсовјетског простора у такозвани „Руски свет“ (или „Русский мир“, на руском). У 19. веку познати руски драматург А.Н. Островски користио је „Руски свет“ као књижевну метафору. На крају 20. века историчар и социјални антрополог В.А. Тишков (Tishkov, 1993a; Tishkov, 1993b) увео је овај термин у научни дискурс сматрајући га феноменом глобалних размера. Ми смо себи поставили задатак да проучавамо социјална очекивања Белоруса у погледу интеграције како са Русијом (језгром Руског света), тако и са Европском унијом.

Резултати републичког истраживања јавног мњења Белорусија-2030, које је 2014. године спровео Институт за социологију Белорусије, постали су главна емпиријска база. Истраживање је спроведено насумичним узорковањем, с контролисаним уделом становништва старијег од 16 година у односу на област становања, пол, старост и образовање. Репрезентативност узорковања осигурана је поштовањем следећих принципа: узорак пропорционално обухвата становништво Минска (издвајајући град Минск), Могилевске, Витебске, Гроднејске, Гомељске и Брестјске регије; градско и рурално становништво; у регионима је пропорционално заступљено становништво шест „подручја“ (1- град Минск и административни центри; 2 - градови са 100 до 250 хиљада становника; 3 - градови са 50 до 100 хиљада становника; 4 - градови са 10 до 50 хиљада становника; 5 - насеља градског типа са мање од 10 хиљада становника; 6 - рурално становништво). У сваком „подручју”, пропорционално је заступљено становништво према полу, старости, образовању. 
Обим узорка је 1495 испитаника. Граница грешке узорковања је пет процентних поена. Такође, коришћени су подаци за праћење кретања из различитих година.

\section{Резултати: одабир источног смера, западног смера - још увек кроз Русију}

Белоруска спољна политика традиционално се посматра са становишта избора између Европске уније и Русије (Allison, White, Light, 2005; Rotman \& Veremeeva, 2011; Marples, 2013). Као што смо сазнали, то што је Белорусија била део СССР-а више од 70 година повезује Републику са Руском Федерацијом у политичком и економском смислу. Шта се може рећи о социо-културним интересима Белорусије и Русије? Колики је осећај заједништва између Белоруса и Руса и на чему се заснива? Како се ово јединство примењује у међудржавним односима?

Желели бисмо да почнемо проучавање друштвеног става Белоруса према интеграцији одговарањем на следеће питање: Да ли белоруски нароg виgи своју земљу као независну и самоодрживу яржаву? Године 2014, 36,3\% испитаника је одговорило „да“ на то питање, 38,6\% - „углавном да“, 8,1\% - „углавном не“, 3,5\% - „не“, $13,3 \%$ - било је неодлучно, 0,2\% - није дало одговор. Тако 74,9\% Белоруса (укупан удео одговора „да“ и „углавном да“) своју земљу види као независну и самоодрживу државу. Међутим, као одговор на питање - Какву йозицију Белорусије у међународној арени желийе у нареgних 10-15 іодина?- 22,3\% одабрало је само опцију да држава сачува неутралност и да не буде у било каквим унијама и блоковима. Већина становништва Белорусије $(53,6 \%)$ залагала се за различите облике и правце интеграције: $30,5 \%$ би желело да Белорусију види као део Евроазијске економске уније (Русија, Белорусија, Казахстан итд.), 12,2\% - као чланицу Европске уније, 10,9\% - као републику која је део Руске Федерације.

Преосталих $24,1 \%$ било је неодлучно $(21,8 \%)$ или је дало алтернативне одговоре (2,3\%). На питање Да ли се залажеиее за блиску [истиакнуйо оg стиране ауйора] инйеіращију Белорусије и Русије? 3/4 испитаника је углавном одговорило потврдно: 42,6\% - „да“, 32,5\% - „углавном да“; 6,8\% - „углавном не“, 2,9\% - „не“, 14,9\% - било је неодлучно, 0,3\% - није одговорило. Ово је процена ставова Белоруса према интеграцији коју је пружила државна установа - Институт за социологију. Истовремено, недржавне истраживачке институције за област социологије потврђују геополитички избор Белоруса у корист уније са источним партнером. Национална репрезентативна студија случаја о питању - Шйа би Белоруси раgије изабрали: савез са Русијом или Евройском унијом? - спроведена је 2016. године. Главно питање било је формулисано на следећи начин: У којој би савезној gржави, ирема вашем мишљеюу, нарояу Белорусије било боле: у савезу са Руском Феgерацијом или Евройском унијом? Расподела одговора је следећа: проруски став је изразило око 65\% испитаника, проевропски став - 20\% испитаника (Pieliasa, 2017).

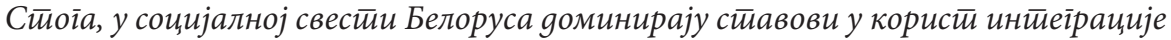

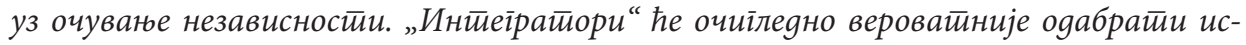

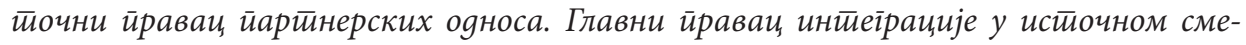
ру ярушитвене свестии била би Русија. Колико је данас снажан истиони ӣраваи, у инӣеірацији? 
Да бисмо проценили могућу динамику социјалних ставова о интеграцији, прво смо упоредили дистрибуцију одговора испитаника различитих старосних група. Унутар група млађих од 40 година, они који су изразити заговорници интеграције Белорусије и Русије чине $32,8 \%$ до $34,3 \%$, док се у старосним групама од 40 и више година тај удео креће од $44,8 \%$ до 53,2\%. То значи да ће Белоруси старији од 40 година, који су детињство или младост провели у совјетском периоду, вероватније репродуковати друштвене стереотипе о томе да је Русија старији брат. „Ми, Белоруси, с братском Русијом тражисмо путеве ка срећи“, то су први стихови белоруске државне химне на руском језику када је била део Совјетског Савеза као Белоруска Совјетска Социјалистичка Република. Као што се види из горе наведеног, старија генерација подржава интеграцију с Русијом више од оне млађе. Друго, међу Белорусима с високим образовањем, удео оних који се изразито залажу за чврсту интеграцију (одговор „да“) износи $39,8 \%$, а међу онима који су изразито против ње (одговор „не“) - 4,9\%. Одговарајући удео унутар ниже образовних група је између 42,0 до 44,0\% и 1,7 до 2,7\%, респективно. Као што се види, ниво образовања не утиче на друштвени став белоруског становништва према интеграцији с Русијом. Треће, међу градским становништвом удео људи који генерално подржавају уску интеграцију с Русијом (збир удела одговора „да“ и „углавном да“) износи 73,5\% (43,2 + 30,3\%), а међу руралним становништвом достигао је 79,7\% (40,8 + 38,9\%). Удео оних који су против интеграције (укупан број одговора „не“ и „углавном не“) је сличан - 11,1\% (3,4 + $7,7 \%)$ и $5,7 \%(1,3+4,4 \%)$, респективно. Место боравка такође нема снажан утицај на формирање друштвеног става према интеграцији. Као резултат тога, представници старијих старосних група у већој мери подржавају блиску интеграцију с Русијом; грађани с високим образовањем у мањој мери фаворизују блиску интеграцију с Русијом; градско становништво залаже се за блиску интеграцију с Русијом мање него рурално становништво.

Теоретски, база подршке оних који заговарају блиску интеграцију с Русијом могла би да се смањи због урбанизације, повећања удела становништва с високим образовањем и природног пада броја становника, пре свега, код старијих старосних група. У том случају, интеграција Белорусије с Русијом као друштвени пројекат могла би да се упореди с топљењем арктичког леда. Наизглед још увијек монументалан, сваке године постаје све крхкији и рањивији. Међутим, после кризне 2009. године, економска интеракција између Белорусије и Русије се појачала: успостављена је царинска унија, Антикризни фонд Евроазијске економске заједнице (претходник ЕАЕУ) подржао је Белорусију током кризе, а Русија је поново обезбедила повлашћене цене нафте и гаса за Белорусију. Као резултат тога, после кризних година 2009-2011, група испитаника с негативним ставом према развоју блиских односа између Белорусије и Русије постала скоро двоструко мања Табела 1.

Међутим, говорећи о Евроазијској економској унији, не треба заборавити на Савезну државу Русије и Белорусије (или Савезну државу). Формирање ове уније покренуло је успостављање других структура на бившој совјетској територији, укључујући Евроазијску економску унију. А, сама чињеница да Савезна држава није престала да постоји доказује да, упркос новим интеграционим ентитетима, Белорусија и Русија остају најближи политички, економски и војни савезници. Томе у прилог иду и резултати друштвеног истраживања на таму белоруско-руске 
интеграције из 2014. године (Shavel, 2015). Дакле, по питању дефинисања главних циљева даљег развоја Савезне државе Русије и Белорусије, становништво сматра да је обједињавање ресурса две земље најважнији фактор: Белорусија - 45,2\%, Русија - 46,2\%. 34,5\% Белоруса (треће место) и 35,6\% Руса (друго место) циља на снажну и моћну државу којом се може поносити. 26,7\% Белоруса и $31,7 \%$ Руса (сваки на четвртом месту) виде вредност даљег савезништва двеју словенских република у погледу сузбијања спољних претњи. Међутим, ни Руси (19,9\%) ни Белоруси $(15,0 \%)$ Савезну државу не виде као државу која ће вратити СССР. Ипак, два пута више Руса него Белоруса сматра да би Унија морала да има заједнички политички систем (43,8\% према $21,8 \%)$, економски систем (49,5\% према $24,7 \%)$ и идеологију $(57,6 \%$ према 24,2\%) (Shavel, 2015, стр. 46). Пошто Белорусија има мање искуства, размена

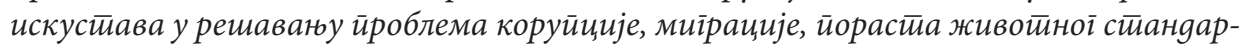
ga важнија је за Белорусе, него за Русе (Белорусија - 38,7\%, 2. место; Русија - 31,6\%, 5. место).

Интегрисање Белорусије и Русије у једну државу више пута је било врућа тема. Већ крајем 1998, председници А. Лукашенко и Б. Јељцин потписали су Декларацију о даљој интеграцији народа Белорусије и Русије. Овом декларацијом проглашена је намера за стварањем заједничке савезне државе (која је на крају створена - Савезна држава Русије и Белорусије) и остављена је могућност референдума о овом питању. Резултати анкетирања становништва Белорусије и Русије показали су да су Белоруси били више резервисани по питању уједињења („за“ - 54,9\%) него Руси („за“ 72,0\%) (Drakohurst, 1999, стр. 79). У том контексту, ту је и јединствена чињеница да je 1999. године током анкетирања белоруским испитаницима постављено питање „Ако би се основала канцеларија председника Белорусије и Русије, за кога бисте гласали на изборима?", а где је било могуће именовати само једног политичара (Drakohurst, 1999, стр. 80). Само питање није изазвало никакву забринутост или иритацију испитаника. Успостављање такве канцеларије чинило се природно - и прилично могуће. Резултат је био да би 38,4\% испитаника изабрало А. Лукашенка за председника Белорусије и Русије, укључујући млађу популацију - 25,7\%. Најближи ривал био је руски политичар Г. Јавлински - 5,2\% (укључујући млађу популацију $4,5 \%)$ који је био рангиран на другом месту. Тадашњи председник Б. Јељцин освојио је мање од 1\% гласова због лошег имиџа и здравствених проблема. Шта је био разлог високог рејтинга белоруског у односу на руског лидера? Крајем деведесетих година прошлог века, Русија је изгубила Чеченски рат, остала је у рушевинама после пада 1998. године, а глад је почела у многим регионима. Зато се на крају деведесетих Белорусија на челу са А. Лукашенком многлим Русима чинила врло привлачном. Чинило се да се растућа криза у Русији може превазићи следећи пут Белорусије. Већ деведесетих година прошлог века Белорусија се консолидовала под владавином једне особе и била је административна држава. Пре него што је Владимир Путин преузео председничку функцију, Русија је у том погледу била слабија. Тренутно Москва има свог снажног лидера. Будући да су обе државе јаке и добро руковођене, питање уједињења је врло тешко.

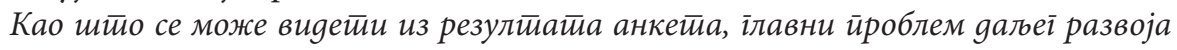

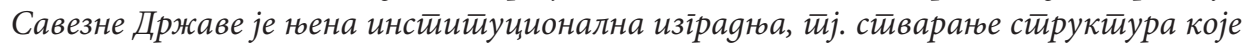
би ирреузеле иниетрационе функиије и усиетно их сировеле. Тренуйно су Белоруси, 
за разлику оg Руса, заgовољни ӣостиојећим разликама између инсииитиуционалних

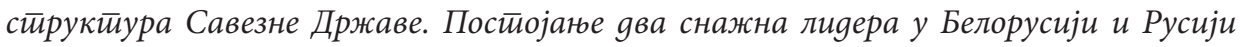
чини иичйане ујединень двеју земать мане релеванйним.

У датим околностима, усмеравамо вашу пажњу на следећу занимљиву чињеницу. Када говоре о јачању интеграције са Русијом, Белоруси нису спремни да пројектују „кримску кризу“ на своју земљу (Tut.by, 2017). Тако, 68,3\% сматра да је инкорпорација Белорусије од стране Русије, као што је то био случај и са Кримом, мало вероватна. Само 14,1\% сматра да су могуће сличне акције Русије према Белорусији. Већина Белоруса $(65,7 \%)$ подржала је одлуку о руској анексији Крима 2014. године. Само 13,5\% је тај акт прогласило незаконитим. Иако је званични Минск заузео неутралан став у руско-украјинском сукобу, став друштва да је руски Крим својевремено дат Украјини као поклон остаје и даље јак. Руски масовни медији активно подржавају такав став (на пример, популарна новина

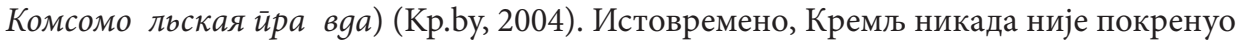
тему руске анексије Белорусије (Belsat.eu, 2015). У Белорусији је удео становништва које мисли да Републику треба интегрисати у Руску Федерацију као подређени ентитет отприлике 5-6\% Табела 2.

Када се појаве тешкоће са функционисањем различитих унутардржавних ентитета на постсовјетској територији, Савезна држава Русије и Белорусије је полазна основа за развој интеграција бивших совјетских република. Према нашем мишљењу, Савезна држава тренутно је више од политичког и економског пројекта. Савез Белорусије и Русије има снажну социо-културну основу. У нашем истраживању, социо-културни фактори сврстани су у четири најутицајнија фактора који уједињују белоруски и руски народ, док су економски, политички и други заједнички интереси на петом месту Табела 3.

Расположење белоруских грађана снажан је фактор успешне примене друштвених ставова Белоруса према интеграцији. Као одговор на питање „Какав осећај

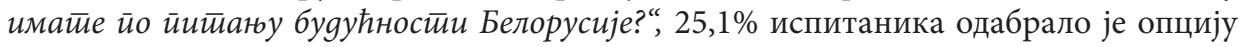
„сигурност у бољи живот“; 45,0\% - „наду у побољшање живота“; 4,9\% - „апатичност и равнодушност“; 9,6\% - „забринутост због могућег погоршања живота“; 6,5\% - „забринутост због стварног погоршања живота“; 8,6\% - било је неодлучно; 0,3\% - није одговорило. Ако информативне одговоре рангирамо од 1 (минимум) до 5 (максимум), показатељ друштвеног оптимизма на петостепеној скали износиће 3,8 . С обзиром на горе наведено, прилично су интересантни одговори на питање: „Која од следећих претњи, по вашем мишљењу, угрожава Белорусију у наредних 10-15 година?“. Да бисмо проценили значај одређеног ризика у свести белоруских грађана, узели смо у обзир део испитаника који су одабрали опцију „Ово је сасвим могуће“. Оцена укључује ризике који могу бити резултат процеса интеграције или се на њих односе. Као што видимо, удео оних који страхују од прилива миграната као спољног фактора несигурности је висок (30,5\%). Отприлике три пута мање испитаника је поменуло стварни ризик од различитих врста етничких или верских сукоба унутар државе $(11,4 \%)$ (Табела 4 ).

Као што се може видети, Белоруси не виде стварну опасност од губитка суверенитета $(7,9 \%)$. Грађани Републике настављају активно да подржавају приступање различитим економским савезима Табела 5. 


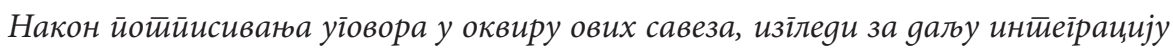
земата су одмах йостили вияљиви. Како је формиране Царинске уније, Зајеуничкоі економскоі йростиора, Евроазијске економске зајеgнице, Евроазијске економске уније добило широку йокривености у националним меgијима, йоgаци социолошкоі истираживана ойкрили су висок ниво йоgрике јавностии уласку Белорусије у ове уније.

Највеће користи и предности придруживања Белорусије Евроазијској економској унији, према мишљењу испитаника (2014), јесу: 1) развој тржишта за продају белоруске робе и услуга, стварање повољнијих услова (бесцаринска трговина, итд.) $(49,8 \%) ; 2)$ могућност добијања финансијске и друге врсте подршке у условима кризе и глобалне финансијске нестабилности $(44,6 \%) ; 3)$ добијање енергената по повлашћеним ценама $(37,4 \%)$. Удео оних који би желели да добијају енергенте по повлашћеним ценама вероватно ће постепено опадати, јер је у старосној групи од 40 и више година тај удео износио 40,6\%, а у старосној групи испод $40-33,7 \%$. То значи да се млађа генерација, у поређењу са старијом генерацијом, у мањој мери ослања на олакшице из Русије. Чини се да Руси имају сличне ставове. Према подацима Сверуског центра за истраживање јавног мњења, Руси у доби од 45 до 59 година теже фаворизирању једнаких цена енергената у савезним државама (64,0\%), док код младих између 18 и 24 године тај удео износи 44,0 \% (VTSIOM, 2017).

Могуће негативне последице придруживања Белорусије Евроазијској економској унији су следеће: миграција најквалификованијих стручњака у земље Евроазијске економске уније $(41,8 \%)$; повећање царина и цена низа роба, као и губитак конкурентности белоруске робе и услуга на домаћем тржишту у односу на производе и услуге из других земаља Евроазијске економске уније (31,9\% свака); дестабилизација белоруске економије после приступања Републике Заједничкој економској унији. (21,7\%); пренос овлашћења за решавање кључних питања економског развоја на национални ниво, као и губитак или „замагљивање“ националне културе и традиције (оба по 18,1\%). Подаци из 2016. показују да Белоруси бирају економске и политичко-војне циљеве као приоритетне циљеве функционисања Евроазијске економске уније Табела 6.

Што се тиче дискусије о будућности Белорусије у интеграцији са другим земљама, ослањамо се на резултате студије „Млади људи на постсовјетском простору: слике света, вредности, стратегије самоостварења“, спроведене у периоду октобар 2017 - фебруар 2018. међу студентима водећих универзитета у Белорусији и Русији (Andreev, Lashuk, 2019a; Andreev, Lashuk, 2019b). Према секундарној анализи налаза ове студије, белоруски студенти имају више позитивних него негативних ставова према западном свету. На пример, у белоруском узорку је забележено $28 \%$ позитивних и 5\% негативних реакција на реч „Европска унија“, а у руском узорку - $14 \%$ и $10 \%$; такође, у Белорусији реч „Запад“ изазвала је $34,5 \%$ позитивних и 7\% негативних реакција, у Русији - 27\% и 7\%. Белоруски студенти високо цене Руску Федерацију као важног партнера у Савезу Русије и Белорусије, повезујући Русију првенствено с речима „снага“ (64\%) и „традиција“ (25\%). Студенти су такође оценили историјски пут који су одабрале њихове земље: у Русији је однос између оптимиста и песимиста у групи студената приближно 1: 1,5 (24\%), док у Белорусији он достиже готово 1: 4 (42\%), с тим што се руска омладина окреће искуству савремене Кине у погледу тражења нових модела друштвеног развоја (такво понашање није типично за младе 
из Белорусије). Горе наведено такође важи за интеграцију. Млади Руси подржавају разне иницијативе за интеграцију, а Белорусија је један од водећих партнера - више од $88 \%$ руских студената изразило је одобравање. Међутим, Белорусија је заузела друго место на листи приоритета, после Кине. За потребе поређења, 82\% руских студената би желело да развије интеграцију са Казахстаном, 75\% са Европском унијом, 52\% са Организацијом Северноатлантског споразума (НАТО), 42\% са Украјином. Тако ће Белорусија остати лидер у интеграцији са Русијом када је реч о окупљању руског света, а пре свега то је случај са Заједницом независних држава, Савезном државом Русије и Белорусије и Евроазијском економском унијом.

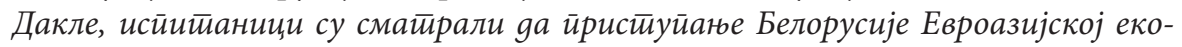
номској унији има несйорне йреgностии (слоболно кретиане робе, услуїа и финансија, йойусиии на руске енеріентие) и оgређене неgостиаике (на йример, миірација раяне снаїе, йовећане ияарине за извоз нафйе и сматен ниво економских реформи земль). Друшитвено-економски и војно-ӣолитички цилеви сврстиани су на највише местио међу цильевима иниетірације у Евроазијску економску унију. И белоруски и руски млаgи фаворизују комериијализаиију односа између савезних яржава.

\section{Закључак}

Укратко, данашња спољна политика Републике Белорусије садржи два основна постулата - независност државе и мултивекторску интеграцију. Ипак, добро избалансирана уравнотежена спољна политика коју је званично прогласио белоруски председник очито је оријентисана ка Истоку. У интеграционим процесима такође постоји снажан наклон према Русији из историјских и економских разлога. Иако већина белоруске популације подржава различите облике и векторе интеграције, Белоруси не желе да се придруже Европи. Главни правац јавног мњења Белорусије у погледу интеграције је пре свега Русија. Друштвени ставови белоруског становништва у погледу интеграционих односа са Русијом усидрени су на друштвеном стереотипу о ставу према Русији као „старијем брату“. Ипак, ниво партнерства који не угрожава постојање Белорусије као независне државе и не спречава Белорусију да се врати у породицу европских народа испунио би националне интересе Белоруса. Односно, Белоруси имају за циљ да сачувају независност и буду уз Русију.

Што се тиче заједничке политике са Русијом, неуспеси источног суседа у међународној арени имају повратни ефекат на Белорусију као источног партнера. Тренутна неравнотежа источног и западног вектора белоруске спољне политике значајно утиче на белоруски национални идентитет и њену међународну позицију. Погоршање односа са Западом негативно утиче на социо-економску ситуацију Белорусије и њен међународни статус. Нормализација односа са водећим земљама Запада и утицајним међународним организацијама као што су Европска унија, Савет Европе, НАТО и Међународни монетарни фонд је приоритетни правац спољне политике Републике Белорусије. У циљу смањивања одређених негативних последица кремљске политике по Белорусију са становишта међународне заједнице, Република је званично неутрална. Ова позиција је посебно изражена у погледу војних и политичких сукоба. Позитивни аспекти руске спољне политике пројектовани су и на Белорусију, а Белоруси је узимају здраво за готово. 
Интеграција Белорусије с Русијом заснована је на моћном социокултурном темељу - заједничкој прошлости, сличној култури, заједничком језику, породичним везама, међуетничким браковима. Културно-историјски фактори доминирају ставовима Белоруса о интеграцији с Русијом, док став према чланству у Евроазијској економској унији јасно обликују економске наде и очекивања: развој тржишта, додатне могућности улагања и повлашћене цене увезених енергената. Такође се јавља тренд ка прихватању комерцијализације односа између Белорусије и Русије, посебно међу младим људима. У будућности ће главни проблем развоја интеграције постсовјетских земаља (и у оквиру Евроазијске економске уније) бити стварање институција и других структура које би преузеле и успешно примениле интеграционе функције. Тренутно је савез Белорусије и Русије који се заснива на заједничкој историјској, социо-културној, економској и политичкој прошлости најјачи на територији бившег Совјетског Савеза.

\section{REFERENCES / ЛИTEPATУPA}

Alekseev, A.M., Vikentyev, A.I., Miroshnichenko, B.P. (1975). Socialist integration and its advantages over the capitalist. Moscow: Nauka. [In Russian]

Allison, R., White, S., Light, M. (2005). Belarus between East and West. Journal of Communist Studies and Transition Politics, vol. 21 (4), 487-511.

Andreev, A.L., Lashuk, I.V. (2019a). Russian and Belarusian Students: World Views, System of Values, Self-Actualization Strategies. Part I. Sociologicheskaya nauka $i$ social'naya praktika, vol. 7, № 1(25), 72-82.

Andreev, A.L., Lashuk, I.V. (2019b). Russian and Belarusian Students: World Views, System of Values, Self-Actualization Strategies. Part II. Sociologicheskaya nauka $i$ social'naya praktika, vol. 7, № 2(26), 34-45.

Belsat.eu (2015, April, 15). Lukashenka: Putin Never Raised Issue of Belarus' Joining Russia, but 'Reacts Emotionally' to Challenges. Available at http://belsat.eu/en/news/ lukashenka-putin-never-raised-issue-belarus-joining-russia-reacts-emotionallychallenges/

Drakohurst, Yu. (1999). Foreign policy preferences of young people of Belarus. In: Manaev, O.T. (eds.) Youth and Civil Society: Belarusian Version (pp. 73-94). Minsk: Izd. V.M. Skakun. [In Russian]

Korosteleva, E.A. (2009). The Limits of the EU Governance: Belarus' Response to the European Neighbourhood Policy. Contemporary Politics, Vol. 15 (2), 229-245.

Kp.by (2004, February, 18). 50 years ago, Khrushchev presented the Crimea to Ukraine. Available a http://www.kp.by/daily/23219/26731/[In Russian]

Marples, D. (2013). Between the EU and Russia: Geopolitical Games in Belarus. The Journal of Belarusian Studies, vol. 7 (1), 38-68.

Pieliasa, S. (2017, February, 14). Sociologist: 5-7\% Belarusians would have Belarus join Russia. Available at http://belsat.eu/en/news/andrej-vardamatski-za-uvahod-u-sk lad-rasei-5-7-respandentau-u-belarusi/ 
Rotman, D., Veremeeva, N. (2011). Belarus in the Context of the Neighbourhood Policy: Between the EU and Russia. Journal of Communist Studies and Transition Politics, vol. 27 (1), 73-98.

Shavel, S.A. (2015). Social Purposes Attribution of Further Union State of Belarus and Russia Consolidat. Sociologicheskij Almanah, vol. 6, 44-53. [In Russian]

Tishkov,V.A. (1993a). Russians in Central Asia and Kazakhstan. In "Issledovaniya po prikladnoj i neotlozhnoj etnologii”, vol. 51. Moscow: IEA RAN. [In Russian]

Tishkov,V.A. (1993b). Russians as minorities (example of Estonia). In "Issledovaniya po prikladnoj i neotlozhnoj etnologii”, vol. 52. Moscow: IEA RAN. [In Russian]

Tut.by (2017, May, 17). Opinion Poll: 7\% of Belarusians Want to Have Visas with Russia, Every Sixth Wants Unification of Two Countries. Available at https://news.tut.by/ economics/543469.html. [In Russian]

VTSIOM (2017, February, 17). VTSIOM: Russians Consider Belarus a Friend, but Against the Discount on Gas for Her. Available at https://rusreality.com/2017/02/17/vtsiomrussians-consider-belarus-a-friend-but-against-the-discount-on-gas-for-her [In Russian]

Wallerstein, I. (2004). World-Systems Analysis: An Introduction. Durham, North Carolina: Duke University Press.

\section{APPENDIX / ПРИЛОЗИ}

Табела 1. Погледи на динамику односа између Белорусије и Русије, према популацији Белорусије, \%

Table 1. Views on the relationship dynamics between Belarus and Russia, according to the population of Belarus, $\%$

\begin{tabular}{|l|c|c|c|c|c|c|}
\hline $\begin{array}{c}\text { Одабрани одговор/ } \\
\text { Selected answer }\end{array}$ & 2009 & 2010 & 2011 & 2012 & 2014 & 2015 \\
\hline $\begin{array}{l}\text { Значајно бољи/ } \\
\text { Significantly improved }\end{array}$ & 5,2 & 4,5 & 5,1 & 12,8 & 20,2 & 15,6 \\
\hline $\begin{array}{l}\text { Мало бољи/ } \\
\text { Slightly improved }\end{array}$ & 17,0 & 14,9 & 23,1 & 29,5 & 26,5 & 25,0 \\
\hline $\begin{array}{l}\text { Непромењени/ } \\
\text { Did not change }\end{array}$ & 28,4 & 25,8 & 22,9 & 23,2 & 27,7 & 35,5 \\
\hline $\begin{array}{l}\text { Мало гори/ } \\
\text { Slightly deteriorated }\end{array}$ & 14,4 & 20,9 & 16,9 & 11,8 & 4,2 & 8,7 \\
\hline $\begin{array}{l}\text { 3начајно гори/ } \\
\text { Significantly deteriorated }\end{array}$ & 2,6 & 5,2 & 5,3 & 1,3 & 0,4 & 0,8 \\
\hline $\begin{array}{l}\text { Hеодлучан/ } \\
\text { Undecided }\end{array}$ & 32,3 & 28,7 & 26,7 & 21,3 & 20,9 & 14,4 \\
\hline
\end{tabular}


Табела 2. Погледи на перспективу даљег развоја односа интеграције између Белорусије и Русије, према популацији Белорусије, \%

Table 2. Views on the prospects for further development of integration relations between Belarus and Russia, according to the population of Belarus, $\%$

\begin{tabular}{|c|c|c|c|c|c|c|c|}
\hline $\begin{array}{l}\text { Одабрани одговор/ } \\
\text { Selected answer }\end{array}$ & 2009 & 2010 & 2011 & 2012 & 2014 & 2015 & 2016 \\
\hline $\begin{array}{l}\text { Белорусија треба да буде } \\
\text { независна држава, она мора } \\
\text { да изгради односе с Русијом } \\
\text { на основу међународних } \\
\text { уговора/ } \\
\text { Belarus should be an indepen- } \\
\text { dent country, it must build } \\
\text { relations with Russia on the } \\
\text { basis of international treaties }\end{array}$ & 53,8 & 49,4 & 56,8 & 55,3 & 55,7 & 56,9 & 52,0 \\
\hline $\begin{array}{l}\text { Белорусија и Русија треба } \\
\text { да изграде односе по } \\
\text { принципу равноправне уније } \\
\text { двеју држава уз стварање } \\
\text { наднационалних органа } \\
\text { управљања/ } \\
\text { Belarus and Russia should } \\
\text { build relations based on the } \\
\text { principle of an equal union of } \\
\text { the two states with the cre- } \\
\text { ation of supranational govern- } \\
\text { ing bodies }\end{array}$ & 41,2 & 46,5 & 41,0 & 39,3 & 38,7 & 38,8 & 41,6 \\
\hline $\begin{array}{l}\text { Белорусија би требало да се } \\
\text { придружи Руској Федерацији } \\
\text { као субјект федерације/ } \\
\text { Belarus should join the Russian } \\
\text { Federation as a federation } \\
\text { subject }\end{array}$ & 5,0 & 4,1 & 2,2 & 5,4 & 5,6 & 4,3 & 6,4 \\
\hline
\end{tabular}


Олег Кобјак, Ирина Андрас, Сйавови Белоруса о инӣеіращији: између Евройске...

Табела 3. Оцена фактора који уједињују белоруски и руски народ, 2014,\% Table 3. The rating of factors that unite the Belarusian people with the people of Russia, 2014, \%

\begin{tabular}{|l|c|}
\hline Историјски фактор/ Historical past & 57,6 \\
\hline Заједнички језик/ Shared language & 38,1 \\
\hline $\begin{array}{l}\text { Култура (вредности, традиција, обичаји)/ } \\
\text { Culture (values, traditions, customs) }\end{array}$ & 35,6 \\
\hline $\begin{array}{l}\text { Породичне везе, међуетнички бракови/ } \\
\text { Family ties, inter-ethnic marriages }\end{array}$ & 25,8 \\
\hline $\begin{array}{l}\text { Економски, политички и други заједнички интереси/ } \\
\text { Есопотіс, рolitical and other сотmоn interests }\end{array}$ & 22,2 \\
\hline $\begin{array}{l}\text { Супротстављање спољним претњама, безбедност/ } \\
\text { Орроsition to ехternal threats, security }\end{array}$ & 20,7 \\
\hline Особине личности, менталитет/ Реrsonality traits, mentality & 16,0 \\
\hline Религија/ Religion & 15,9 \\
\hline $\begin{array}{l}\text { Припадност истој евроазијској цивилизацији/ } \\
\text { Веlоnging tо а single Eurasian civilization }\end{array}$ & 9,6 \\
\hline Не могу да кажем/ Cannot say & 3,4 \\
\hline Ништа не уједињује/ Nothing unites & 2,2 \\
\hline Друго/ Оther & 1,3 \\
\hline
\end{tabular}

Табела 4. Могуће опасности по Белорусију у наредних 10-15 година, 2014,\% Table 4. Possible dangers for Belarus in the next 10-15 years, 2014, \%

\begin{tabular}{|l|c|}
\hline $\begin{array}{l}\text { Снажан прилив миграната из других земаља/ } \\
\text { Sharp influx of migrants from other countries }\end{array}$ & $30,5 \%$ \\
\hline Пад животног стандарда/ Decline in the living standards & $24,8 \%$ \\
\hline Пораст криминала/ Increase in crime & $20,3 \%$ \\
\hline $\begin{array}{l}\text { Војни ангажман (ван Белорусије)/ } \\
\text { Мilitary еngagement (оutside of Belarus) }\end{array}$ & $17,1 \%$ \\
\hline $\begin{array}{l}\text { Криза националне културе и њена асимилација од стране других } \\
\text { култура/ } \\
\text { Сrisis оf national culture and its assimilation by other cultures }\end{array}$ & $16,7 \%$ \\
\hline Јачање терористичких претњи/ Growth of terrorist threat & $11,7 \%$ \\
\hline $\begin{array}{l}\text { Појава унутрашњих друштвених, етничких, верских и других сукоба/ } \\
\text { Етегgеnсе оf іnternal sосіаl, еthnic, соnfessional and other conflicts }\end{array}$ & $11,4 \%$ \\
\hline Губитак државног суверенитета/ Loss of state sovereignty & $7,9 \%$ \\
\hline $\begin{array}{l}\text { Долазак екстремистичких снага на власт/ Extremist forces coming to } \\
\text { рошеr }\end{array}$ & $5,6 \%$ \\
\hline
\end{tabular}


Табела 5. За приступање Белорусије...,\%

Table 5. In favour of accession of Belarus into..., \%

\begin{tabular}{|c|c|c|c|c|c|c|c|}
\hline \multirow[t]{2}{*}{$\begin{array}{c}\text { Одабрани } \\
\text { одговор/ } \\
\text { Selected } \\
\text { answer }\end{array}$} & \multicolumn{2}{|c|}{$\begin{array}{l}\text { Евроазијској } \\
\text { иаринској } \\
\text { унији/ } \\
\text { The Eurasian } \\
\text { Customs Union } \\
\text { (EACU) }\end{array}$} & \multicolumn{2}{|c|}{$\begin{array}{c}\text { Заједничком } \\
\text { економском } \\
\text { простору/ } \\
\text { Common Eсо- } \\
\text { nотіс Space } \\
\text { (CES) }\end{array}$} & \multicolumn{2}{|c|}{$\begin{array}{c}\text { Евроазијској } \\
\text { економској } \\
\text { заједници (ЕАЭС } \\
\text { или ЕврАзЭС)/ } \\
\text { The Eurasian } \\
\text { Economic Com- } \\
\text { munity (EAEC or } \\
\text { EurAsEC) }\end{array}$} & \multirow[t]{2}{*}{$\begin{array}{c}\text { Евроазијској } \\
\text { економској } \\
\text { унији (ЕАЕУ) } \\
\text { од 01.01.2015./ } \\
\text { The Eur- } \\
\text { asian Eco- } \\
\text { nomic Union } \\
\text { (EAEU) since } \\
01.01 .2015\end{array}$} \\
\hline & 2012 & 2014 & 2012 & 2014 & 2012 & 2014 & \\
\hline Да/Yes & 42,6 & 42,7 & 40,6 & 37,6 & 40,6 & 37,6 & 27,6 \\
\hline $\begin{array}{l}\text { Углавном да/ } \\
\text { Mostly yes }\end{array}$ & 19,6 & 23,0 & 20,7 & 23,6 & 20,7 & 23,6 & 17,1 \\
\hline $\begin{array}{l}\text { Углавном не/ } \\
\text { Mostly no }\end{array}$ & 5,7 & 4,4 & 6,2 & 5,2 & 6,2 & 5,2 & 7,1 \\
\hline $\mathrm{He} / \mathrm{No}$ & 6,0 & 4,6 & 5,4 & 5,8 & 5,4 & 5,8 & 11,7 \\
\hline $\begin{array}{l}\text { Неодлучан/ } \\
\text { Undecided }\end{array}$ & 26,2 & 25,2 & 27,2 & 27,7 & 27,2 & 27,7 & 36,5 \\
\hline
\end{tabular}


Табела 6. Оцена циљева и вредности који би требало да буду у основи интеграционих процеса Евроазијске економске уније, 2016,\%

Table 6. The rating of goals and values that should be at the base of integration processes of the Eurasian Economic Union, 2016, \%

\begin{tabular}{|c|c|}
\hline $\begin{array}{l}\text { Продуктивно запошљавање, слободно кретање грађана, опште } \\
\text { тржиште рада у ЕАЕУ/ } \\
\text { Productive employment, free movement of citizens, general labor } \\
\text { market in the EAEU }\end{array}$ & 33,8 \\
\hline Не знам/ Don't know & 33,3 \\
\hline $\begin{array}{l}\text { Побољшање благостања становништва у државама EAEУ/ } \\
\text { Improvement of the population well-being in the EAEU states }\end{array}$ & 31,5 \\
\hline Колективна безбедност ЕAEУ/ Collective security of the EAEU & 24,8 \\
\hline Заштита људских права/ Protection of human rights & 17,2 \\
\hline $\begin{array}{l}\text { Повољно еколошко окружење у земљама ЕАЕУ/ } \\
\text { Favourable ecological environment in the countries of the EAEU }\end{array}$ & 14,7 \\
\hline $\begin{array}{l}\text { Солидарност свих држава чланица ЕАЕУ против спољних } \\
\text { претњи/ } \\
\text { Solidarity of all the EAEU member states against external threats }\end{array}$ & 13,4 \\
\hline $\begin{array}{l}\text { Одржавање повољних услова за међународну сарадњу/ } \\
\text { Maintaining favorable conditions for international cooperation }\end{array}$ & 12,4 \\
\hline Кохерентан пензијски систем/ Coherent pension protection & 11,2 \\
\hline $\begin{array}{l}\text { Заједнички образовни и културни простор у ЕАЕУ/ } \\
\text { Common educational and cultural space in the EAEU }\end{array}$ & 8,2 \\
\hline Друго/ Other & 0,2 \\
\hline
\end{tabular}

